\title{
Agaricus blazei Extract Induces Apoptosis through ROS-Dependent JNK Activation Involving the Mitochondrial Pathway and Suppression of Constitutive NF- $\kappa$ B in THP-1 Cells
}

\author{
Mun-Ock Kim, ${ }^{1}$ Dong-Oh Moon, ${ }^{1}$ Jin Myung Jung, ${ }^{2}$ Won Sup Lee, ${ }^{3}$ \\ Yung Hyun Choi, ${ }^{4}$ and Gi-Young Kim ${ }^{1}$ \\ ${ }^{1}$ Laboratory of Immunobiology, Department of Marine Life Science, Jeju National University, Jeju, Republic of Korea \\ ${ }^{2}$ Department of Neurosurgery, Institute of Health Science, Gyeongsang National University School of Medicine, Republic of Korea \\ ${ }^{3}$ Department of Internal Medicine, Institute of Health Science, Gyeongnam Regional Cancer Center, Gyeongsang National University \\ School of Medicine, Jinju, Republic of Korea \\ ${ }^{4}$ Department of Biochemistry, Dongeui University College of Oriental Medicine, Busan, Republic of Korea
}

Correspondence should be addressed to Gi-Young Kim, immunkim@jejunu.ac.kr

Received 16 July 2009; Accepted 3 October 2009

Copyright () 2011 Mun-Ock Kim et al. This is an open access article distributed under the Creative Commons Attribution License, which permits unrestricted use, distribution, and reproduction in any medium, provided the original work is properly cited.

\begin{abstract}
Agaricus blazei is widely accepted as a traditional medicinal mushroom, and it has been known to exhibit immunostimulatory and anti-cancer activity. However, the apoptotic mechanism in cancer cells is poorly understood. In this study, we have investigated whether A. blazei extract (ABE) exerts antiproliferative and apoptotic effects in human leukemic THP-1 cells. We observed that $\mathrm{ABE}$-induced apoptosis is associated with the mitochondrial pathway, which is mediated by reactive oxygen species (ROS) generation and prolonged c-Jun $\mathrm{N}$-terminal kinase (JNK) activation. In addition, the ABE treatment resulted in the accumulation of cytochrome $c$ in the cytoplasm, an increase in caspase activity, and an upregulation of Bax and Bad. With those results in mind, we found that $\mathrm{ABE}$ decreases constitutive NF- $\kappa \mathrm{B}$ activation and NF- $\kappa \mathrm{B}-$ regulated gene products such as IAP-1 and -2 . We concluded that ABE induces apoptosis with ROS-dependent JNK activation and constitutive activated NF- $\kappa$ B inhibition in THP-1 cells.
\end{abstract}

\section{Introduction}

Reactive oxygen species (ROS), such as hydrogen peroxides $\left(\mathrm{H}_{2} \mathrm{O}_{2}\right)$, hydroxyl radials $(\bullet \mathrm{OH})$, and superoxide anions $\left(\mathrm{O}_{2}{ }^{-}\right)$, are normally generated by the mitochondria and other intracellular molecules in all aerobes [1]. In general, the redox status is well balanced by the enzyme and nonenzyme systems in cells. Oxidative stress occurs when the critical balance is disrupted by excess ROS production and/or antioxidant depletion [2]. Many chemotherapeutic agents may be selectively toxic to tumor cells because they increase oxidant stress [3-5]. Increased intracellular ROS levels could trigger apoptosis by the activation of the mitochondrialdependent cell death pathway through the activation of mitogen-activated protein kinase (MAPK) pathways and the proapoptotic Bcl-2 proteins Bax or Bad, thus subsequently inducing mitochondrial membrane permeabilization and cell death [4-6].

Nuclear factor-kappa B (NF- $\kappa \mathrm{B})$ is a prominent factor in cell death or survival. Optimal activation of NF- $\kappa B$ requires phosphorylation of the NF- $\kappa \mathrm{B}$ p 65 protein by IKK, along with the activation of a variety of other kinases $[7,8]$. Among the target genes, the inhibitors of apoptosis proteins (IAPs) are believed to be critical cell survival signals. Previous studies have reported that the IAPs bind to caspases and inhibit apoptosis [9], indicating that down-regulation of these proteins and the subsequent activation of caspases is one of the primary mechanisms of apoptosis in various types of cancer cells $[10,11]$. Because NF- $\kappa \mathrm{B}$ can promote cell survival and reduction in its activity leads to apoptosis [1214 ], NF- $\kappa$ B-suppressing agents may be potentially useful in the prevention and treatment of cancer. 
Many natural dietary extracts from mushrooms have been found to be potent in the treatment of various cancers $[15,16]$. Mixed mushroom extracts might contain different chemotherapeutic properties with more than one mechanism of action, thus possessing a combination of different chemotherapeutic effects. Therefore, it is very important to identify the combined effects from mixed mushroom extracts. The basidiomycete mushroom Agaricus blazei has been traditionally used in health foods as a source for the prevention of cancer, hyperlipidemia, arteriosclerosis, and chronic hepatitis. Agaricus blazei extract (ABE) has been reported to have anti-tumor and anti-mutagenic effects [1719]. The intratumoral [20] or oral administration [21] of $\mathrm{ABE}$ also resulted in the infiltration of natural killer (NK) cells in the tumor sites and increased NK cell activity in animals. Our previous studies also demonstrated that $\mathrm{ABE}$ induces the phenotypic and functional maturation of murine bone marrow-derived dendritic cells [22], and it increases apoptosis through Akt dephosphorylation in human leukemic U937 and $\mathrm{G}_{2} / \mathrm{M}$ cell cycle arrest in human gastric epithelial AGS cells, respectively [23, 24]. Although numerous studies on the immunostimulatory effects of $\mathrm{ABE}$ have been reported, the cellular and molecular mechanisms underlying ABE-induced ROS generation and apoptosis are not clear.

In this study, to further elucidate the abilities of ABE-induced apoptosis combined with ROS production, we investigated the effect of $\mathrm{ABE}$ on Jun $\mathrm{N}$-terminal kinase (JNK) activation and NF- $\kappa$ B inhibition in human leukemic THP-1 cells. We report here that ABE increases the intracellular ROS level in a time-dependent manner, and the increase is responsible for its apoptotic effects. ABE-induced ROS activated JNK, leading to mitochondriadependent apoptosis. ABE treatment markedly resulted in the accumulation of cytochrome $c$ in the cytoplasm, an increase in caspase activity, and an upregulation of Bax and Bad. With those results in mind, we found that ABE suppressed constitutive NF- $\kappa$ B activation and NF- $\kappa$ Bregulated gene expression in THP- 1 cells. Finally, the ABEmediated ROS generation closely correlates with the onset of apoptosis.

\section{Methods}

2.1. Reagents. Propidium iodide (PI), paraformaldehyde, 3(4,5-dimethyl-2-thiazolyl)-2,5-diphnyl-2H-tetrazolim bromide (MTT), and $N$-acetyl-cysteine (NAC) were purchased from Sigma (St. Louis, MO). 3,3-Dihexyloxacarbocyanine iodide $\left(\mathrm{DiOC}_{6}\right), 2^{\prime}, 7^{\prime}$-dichlorofluorescein diacetate (DCFDA), and hydroethidine (HE) were purchased from Molecular Probes (Eugene, OR). SP600125 were obtained from Calbiochem (San Diego, CA). RPMI 1640 medium and fetal bovine serum (FBS) were purchased from Invitrogen Co. (Carlsbad, CA) and Gibco BRL (Gaithersburg, $\mathrm{MD})$, respectively. All other chemicals not specifically cited here were purchased from Sigma. ABE was prepared as previously described [23] and was supplied from Daejeon University Oriental Hospital (Daejeon, Republic of Korea).
2.2. Antibodies. Antibodies for IAP-1, IAP-2, Bax, Bad, Bcl2, PARP, caspase- 3 , caspase- 8 , caspase- $9, \mathrm{p} 65, \mathrm{p} 50$ and nucleolin were purchased from Santa Cruz Biotechnology (Santa Cruz, CA). $\beta$-Actin antibody was purchased from Sigma and antibodies for JNK and phospho (p)-JNK were purchased from Cell Signaling (Beverly, MA). Cytochrome $c$ antibody was purchased Chemicon International (Temecula, CA).

2.3. Cell Culture and Viability Assay. Human leukemic THP1 cells were obtained from the American Type Culture Collection (Manassas, VA) and maintained in RPMI 1640 culture medium containing $10 \%$ heat-inactivated FBS and $1 \%$ penicillin-streptomycin (Sigma). Cells were seeded at $2 \times$ $10^{5} \mathrm{cells} \mathrm{ml}^{-1}$, treated with $\mathrm{ABE}$, and then incubated for the indicated time. Cell viability was determined by MTT assay.

2.4. Flow Cytometric Analysis. Cells were fixed in $70 \%$ ethanol overnight at $4^{\circ} \mathrm{C}$. The cells were washed in phosphate-buffered saline (PBS) with $0.1 \%$ BSA. Cells were incubated with $1 \mathrm{U} \mathrm{ml}^{-1}$ of RNase A (DNase free) and $10 \mu \mathrm{g} \mathrm{ml}^{-1}$ of PI overnight at room temperature in the dark. Cells were analyzed using a FACSCalibur flow cytometer (Becton Dickenson, San Jose, CA), and CellQuest software (Becton Dickinson) was used to determine the relative DNA content based on the presence of a red fluorescence.

\subsection{Determination of Mitochondrial Membrane Potential.} Mitochondrial membrane potential was monitored by measuring the uptake of $\mathrm{DiOC}_{6}$. Briefly, cells were harvested, loaded with $50 \mathrm{nM} \mathrm{DiOC}_{6}$ at $37^{\circ} \mathrm{C}$ for $30 \mathrm{~min}$ in the dark, and then analyzed using a flow cytometer.

2.6. In Vitro Caspase Activity Assay. Activity of caspaselike protease was measured using a caspase activation kit according to the manufacturer's protocol (R\&D systems; Minneapolis, MN). This assay is based on spectrophotometric detection of the color reporter molecule $p$-nitroaniline $(p N A)$, which is linked to the end of the caspase-specific substrate. The caspase cleaves the peptide and releases the chromophore $p \mathrm{NA}$, which can be quantified spectrophotometrically at a wavelength of $405 \mathrm{~nm}$.

2.7. Western Blot Analysis. Total cell extracts were prepared using a PRO-PREP protein extraction solution (iNtRON Biotechnology; Sungnam, Republic of Korea). For assay of cytochrome $c$ release, mitochondrial fractions were prepared using a mitochondria isolation kit for mammalian cells (Pierce; Rockford, IL) according to the manufacturer's instructions. The preparation of cytoplasmic and nuclear extracts was conducted using the NE-PER nuclear and cytoplasmic extraction reagents (Pierce). Cell extracts were separated on 8 or $10 \%$ polyacrylamide gels (PAGE), and then transferred to nitrocellulose membranes using standard procedures. The membranes were developed using an ECL reagent (Amersham; Arlington Heights, IL).

2.8. ROS Measurement. Generation of intracellular ROS was examined by flow cytometry using DCFDA for $\mathrm{H}_{2} \mathrm{O}_{2}$ and $\mathrm{HE}$ 


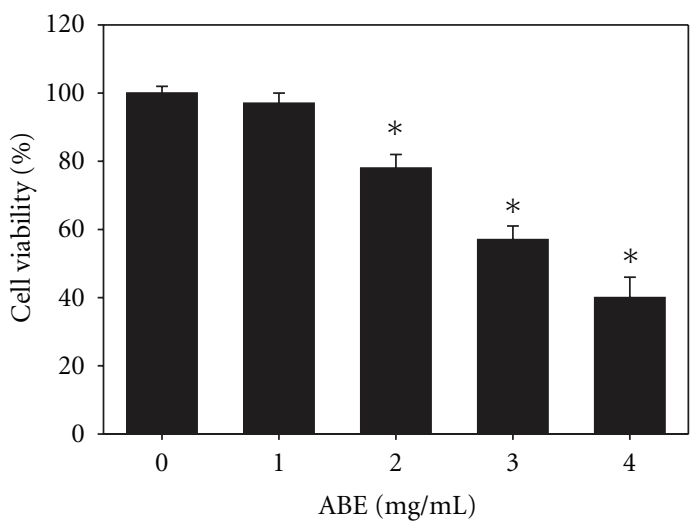

(a)
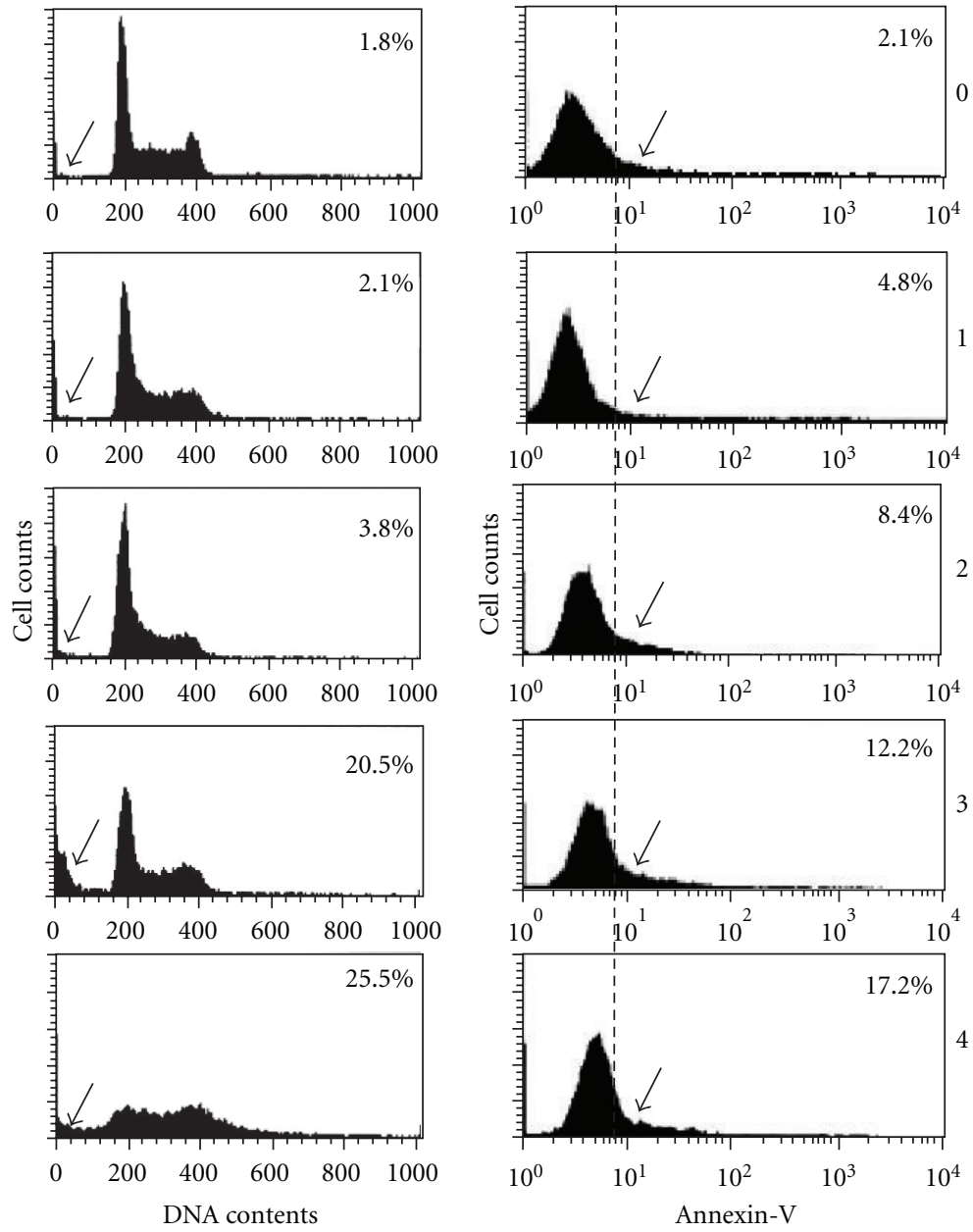

(c)

FIGURE 1: Effect of ABE on cell viability and cell death in THP-1 cells. THP-1 cells were seeded at $2 \times 10^{5}$ cells $\mathrm{ml}^{-1}$ and were then treated with $\mathrm{ABE}$ at the indicated concentrations for $24 \mathrm{~h}$. (a) Cell viability was determined by MTT assay. Each point represents the mean \pm SD of three independent experiments. The significance was determined by Student's $t$-test ( ${ }^{*} P<.05$ versus vehicle control ( 0$)$ ). (b) DNA contents and (c) annexin- $\mathrm{V}^{+}$cells were analyzed by flow cytometer. Percentages represents the sub- $\mathrm{G}_{0} / \mathrm{G}_{1}$ phase and annexin- $\mathrm{V}^{+}$cells, respectively. The results shown are from one representative experiment of three experiments that exhibited similar patterns.

for $\mathrm{O}_{2}{ }^{-}$. The cells were exposed to $4 \mathrm{mg} \mathrm{ml}^{-1} \mathrm{ABE}$ and/or $10 \mathrm{mM}$ NAC for various times, and then treated with $10 \mu \mathrm{M}$ DCFDA and $2 \mu \mathrm{M} \mathrm{HE}$ for $30 \mathrm{~min}$ at $37^{\circ} \mathrm{C}$. Subsequently, the cells were collected, washed twice with PBS, and analyzed for DCFDA and HE fluorescence using a flow cytometer.

2.9. Electrophoretic Mobility Shift Assays (EMSA). DNAprotein binding assays were carried out with a nuclear extract. Synthetic complementary NF- $\kappa$ B (5'-AGT TGA GGG GAC TTT CCC AGG C-3') binding oligonucleotides (Santa Cruz Biotechnology) were 3 '-biotinylated using the biotin $3^{\prime}$-end DNA labeling kit (Pierce) according to the manufacturer's instructions.

2.10. Statistical Analysis. All data were derived from at least three independent experiments. The blots were visualized with Chemi-Smart 2000 (Vilber Lourmat, Marine; Cedex, France). Images were captured using Chemi-Capt (Vilber Lourmat) and transported into Photoshop. Statistical analyses were conducted using SigmaPlot software and values were presented as mean \pm SD. Significant differences between the groups were determined using the unpaired Student's $t$ test. A value of ${ }^{*} P<.05$ was accepted as an indication of statistical significance.

\section{Result}

3.1. ABE Decreases Cell Viability and Induces Apoptosis in THP-1 Cells. To determine the effect of ABE on cell viability, human leukemic THP-1 cells were treated with increasing concentrations up to $4 \mathrm{mg} \mathrm{ml}^{-1}$ and incubated for $24 \mathrm{~h}$. Cell viability was examined using MTT assays. As shown in 


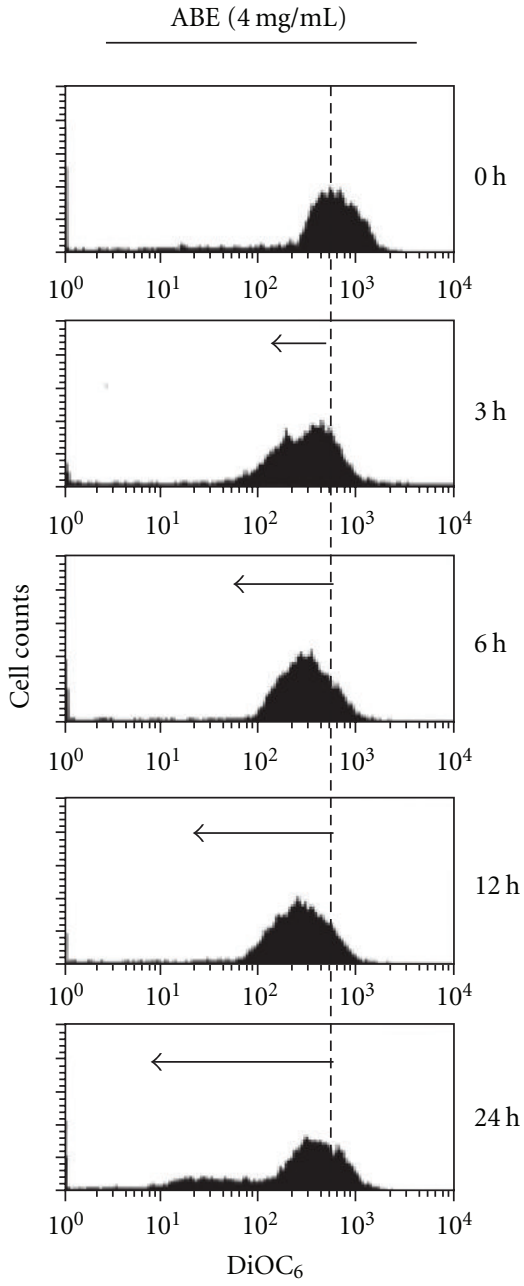

(a)

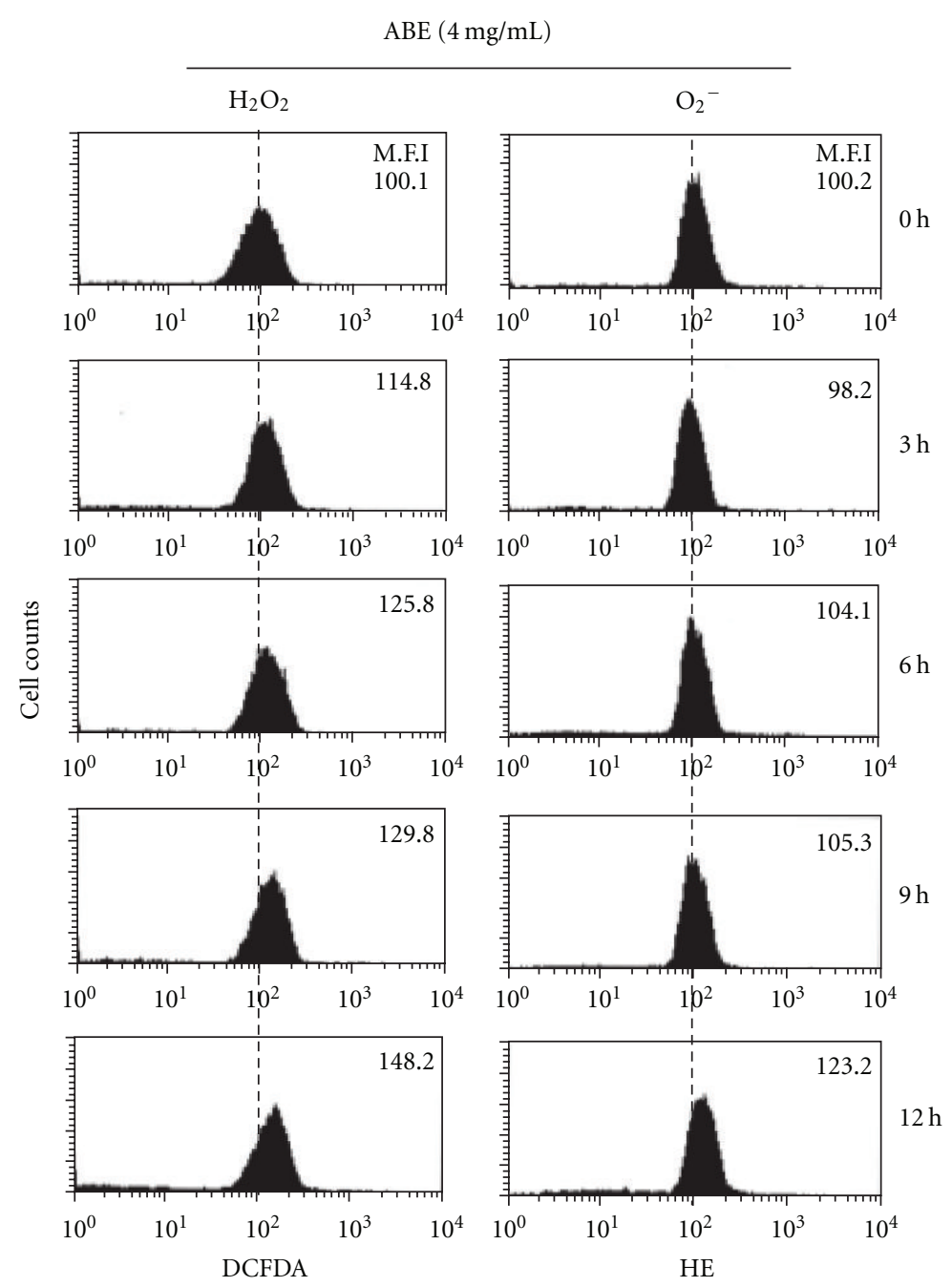

(b)

FIGURE 2: Effect of ABE on mitochondrial function and ROS generation. THP- 1 cells were seeded at $2 \times 10^{5}$ cells $\mathrm{ml}^{-1}$ and were then treated with $4 \mathrm{mg} \mathrm{ml}^{-1}$ of ABE for the indicated time. (a) The mitochondrial membrane potential was determined by flow cytometer using DiOC 6 labeling of mitochondria. (b) The redox status was monitored by the oxidation-sensitive fluorescent dyes for $\mathrm{H}_{2} \mathrm{O}_{2}$ (DCFDA) and $\mathrm{O}_{2}^{-}$(HE). The results shown are from one representative experiment of three experiments that showed exhibited similar patterns.

Figure $1(\mathrm{a}), \mathrm{ABE}$ treatment resulted in a dose-dependent inhibition of viability in THP-1 cells. Indeed, to elucidate the ability of ABE in its anti-viable activity, we analyzed cell cycle distribution using flow cytometry. As shown in Figure 1(b), $A B E$ caused a significant increase in the fraction of sub$\mathrm{G}_{0} / \mathrm{G}_{1}$ phase in a dose-dependent manner. For example, as compared with control, the percentage of cells in sub- $\mathrm{G}_{0} / \mathrm{G}_{1}$ phase was increased more than 10-fold upon treatment with $4 \mathrm{mg} \mathrm{ml}^{-1} \mathrm{ABE}$ for $24 \mathrm{~h}$. Analysis of cell cycle distribution suggests that $\mathrm{ABE}$ treatment might cause apoptosis in THP1 cells. Therefore, we further examined the apoptosisinducing effect of $\mathrm{ABE}$ by annexin- $\mathrm{V}$ analysis. As shown in Figure 1(c), ABE treatment caused significant increases in apoptotic cell percentages as compared with control cells ( $17 \%$ of apoptotic cells in cells with $4 \mathrm{mg} \mathrm{ml}^{-1} \mathrm{ABE}$ for $24 \mathrm{~h}$ ). Therefore, we observed that the proliferation of THP-1 cells was significantly suppressed with an increase of apoptotic percentage in the presence of $\mathrm{ABE}$.

3.2. Mitochondria-Dependent Pathways Are Involved in ABEInduced Apoptosis. To further characterize whether $\mathrm{ABE}$ induces apoptosis by triggering the mitochondrial apoptosis pathway, we investigated the depolarization of the mitochondrial membrane potential and the generation of ROS. When the THP- 1 cells were exposed to $4 \mathrm{mg} \mathrm{ml}^{-1} \mathrm{ABE}$ up to $24 \mathrm{~h}$, the mitochondrial membrane potential was significantly reduced in a time-dependent manner as evidenced by an increase in the proportion of cells with lower fluorescence intensity (Figure 2(a)). As shown in Figure 2(b), treatment with $4 \mathrm{mg} \mathrm{ml}^{-1} \mathrm{ABE}$ also significantly increased the intensity of DCFDA and HE fluorescence (indicating quantification of peroxides and superoxides, resp.). 


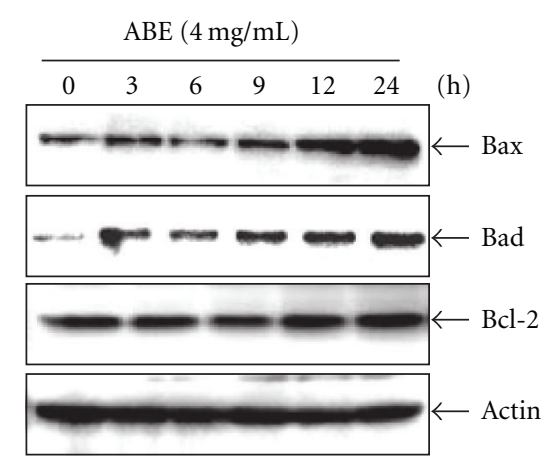

(a)

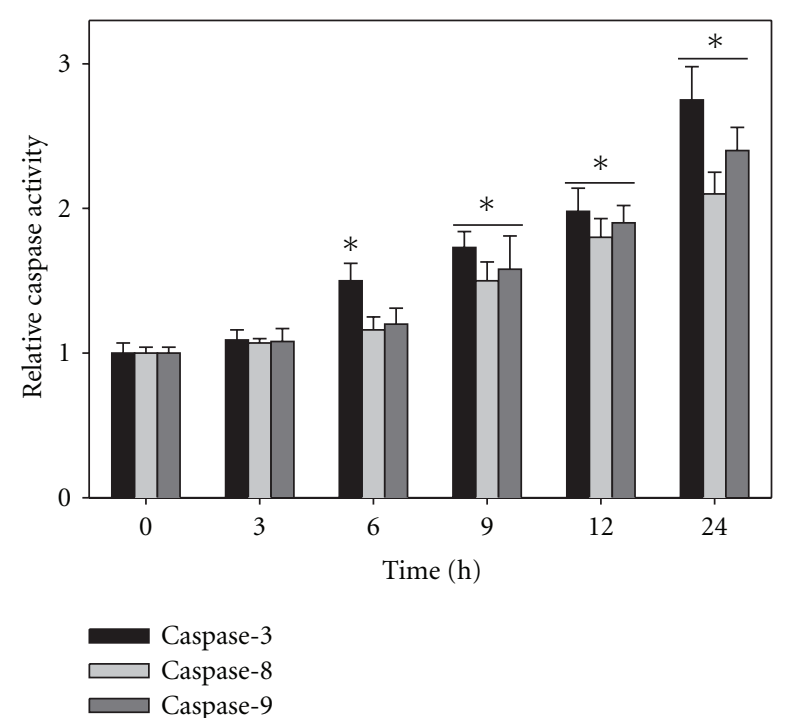

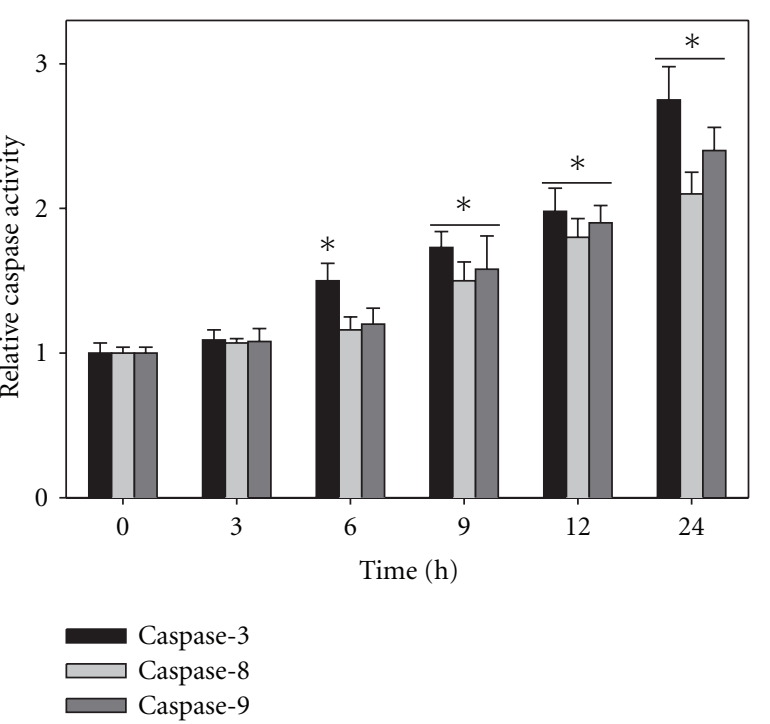

(c)

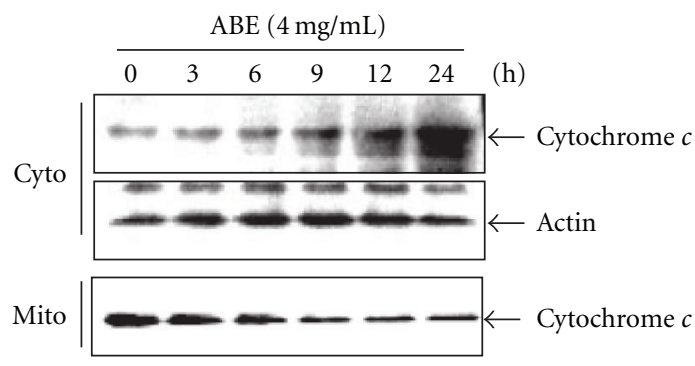

(b)

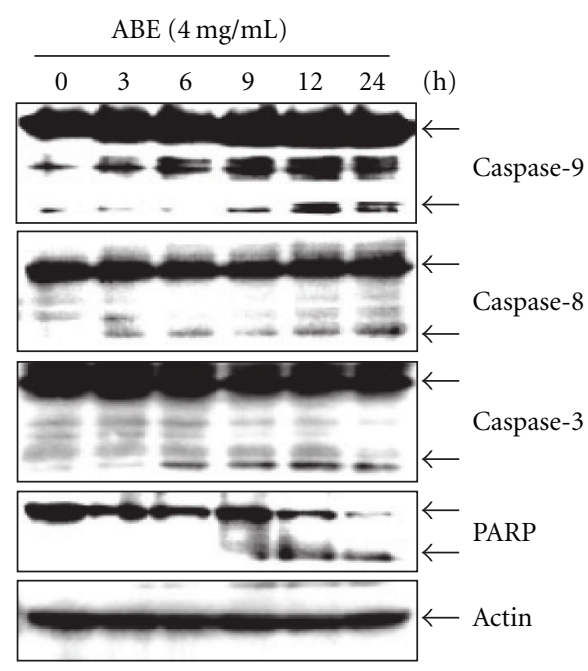

(d)

Figure 3: Effect of ABE on expression of apoptotic proteins. THP-1 cells were seeded at $2 \times 10^{5}$ cells $\mathrm{ml}^{-1}$ and were then treated with 4 $\mathrm{mg} \mathrm{ml}^{-1}$ of ABE for the indicated time. (a) Total cell extracts resolved by SDS-PAGE, transferred to nitrocellulose, and probed with specific antibodies (a) anti-Bax, anti-Bad and anti-Bcl-2; (d) anti-caspase-3, anti-caspase-8, anti-caspase-9 and anti-PARP). (b) Equal amounts of mitochondria and cytosol cell lysates were resolved by SDS-PAGE, transferred to nitrocellulose, and probed with a specific antibody for cytochrome $c$. Equal protein loading was evaluated by $\beta$-actin. The results shown are from one representative experiment of three experiments that exhibited similar patterns. (c) Caspase $(-3,-8$ and -9$)$ activities were determined using caspase assay kits. Each point represents the mean \pm SD of three independent experiments. The significance was determined by Student's $t$-test $\left({ }^{*} P<.05\right.$ versus vehicle control (0)). Cyto, Cytoplasm; Mito, Mitochondria.

We next monitored the activation of caspases and the expression of the pro- and anti-apoptotic proteins. Western blot analysis showed that treatment with $4 \mathrm{mg} \mathrm{m}^{-1} \mathrm{ABE}$ significantly increased pro-apoptotic proteins Bax and Bad, and showed the steady presence of the anti-apoptotic protein $\mathrm{Bcl}-2$ over the course of time (Figure 3(a)). In addition, ABE caused cytochrome $c$ to be released from the mitochondria into the cytosol in a time-dependent manner (Figure 3(b)). We also examined the effect of ABE on caspase activity, as well as cleavage of caspases and PARP in THP- 1 cells treated with $4 \mathrm{mg} \mathrm{ml}^{-1}$ of ABE. As expected, caspase- 9 activity was significantly increased (Figure 3(c)), as ABE induces cytochrome $c$ release into the cytosol (Figure 3(b)). Our results were also showed increased activation of caspase- 8 and -3 (Figure 3(c)). As shown in Figure 3(d), the cleavages of caspase and PARP revealed in a time-dependent manner.
These finding indicate that ABE-induced apoptosis was mediated with the mitochondrial pathway.

3.3. Inhibition of ROS Generation Blocks ABE-Induced Apoptosis. To investigate whether ROS generation is directly associated with $\mathrm{ABE}$-induced mitochondria dysfunction and apoptosis, we assessed these events in THP-1 cells pretreated with NAC $(10 \mathrm{mM})$ for $2 \mathrm{~h}$ followed by treatment with $4 \mathrm{mg} \mathrm{ml}^{-1}$ ABE. As expected, pretreatment with NAC decreased ROS generation and normalized mitochondrial dysfunction caused by ABE in THP-1 cells (Figure 4(a)). To next determine whether pretreatment with NAC could block ABE-induced apoptosis, we performed cell cycle analysis using flow cytometry. As shown in Figure 4(b), ABE caused a significant increase in the fraction of sub$\mathrm{G}_{0} / \mathrm{G}_{1}$ phase, but NAC pretreatment reversed it. For example, 


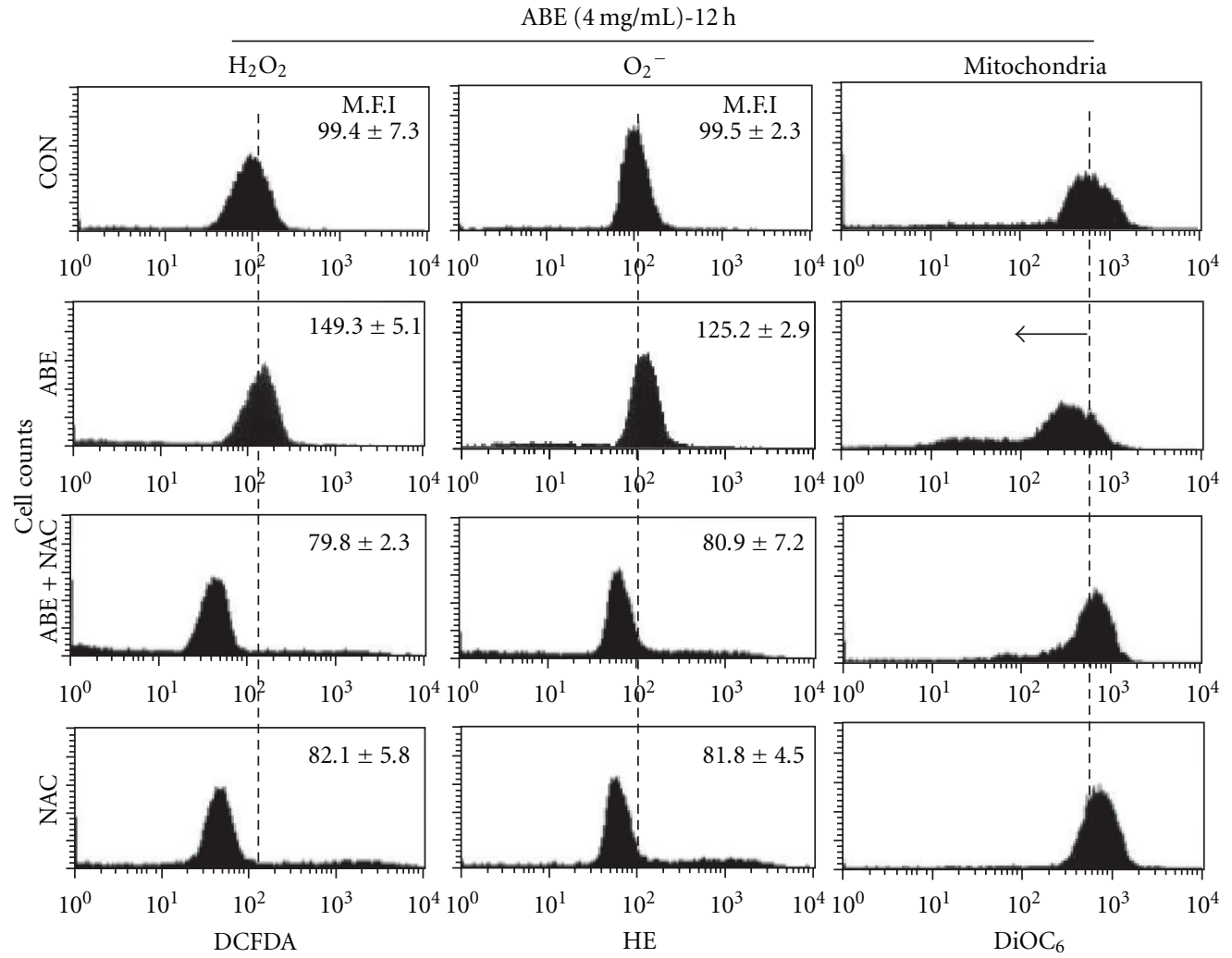

(a)

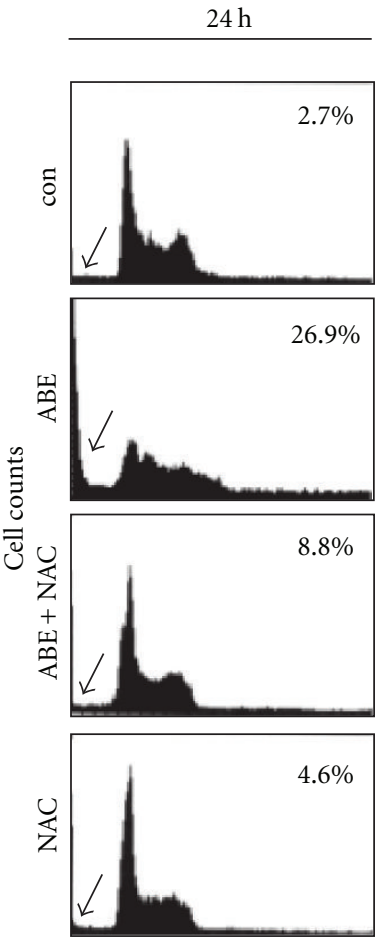

DNA contents

(b)

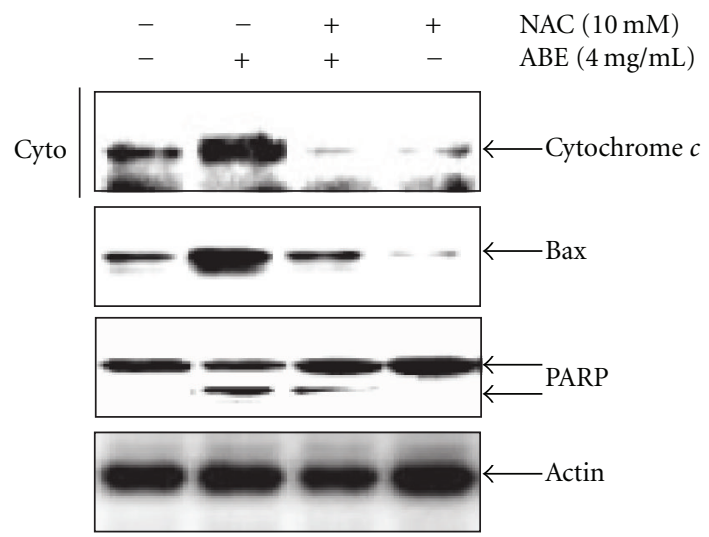

(c)

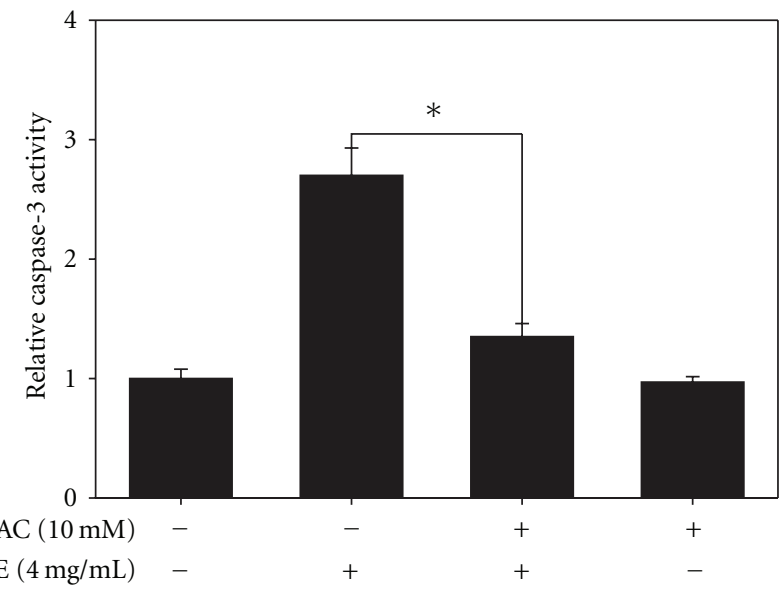

(d)

FIgURE 4: The role of ROS on ABE-mediated apoptosis. THP-1 cells $\left(2 \times 10^{5}\right.$ cells ml $\left.^{-1}\right)$ were pretreated with $10 \mathrm{mM}$ NAC, and then 4 mg $\mathrm{ml}^{-1}$ of ABE was treated for $12 \mathrm{~h} \mathrm{(a)} \mathrm{and} 24 \mathrm{~h}$ (b-d). (a) The redox status was monitored by the oxidation-sensitive fluorescent dyes for $\mathrm{O}_{2}{ }^{-}$and $\mathrm{H}_{2} \mathrm{O}_{2}$. The mitochondrial membrane potential was also determined by flow cytometer using DiOC labeling of mitochondria. (b) DNA contents were analyzed by flow cytometer. The sub- $\mathrm{G}_{0} / \mathrm{G}_{1}$ DNA fractions, indicating apoptosis, were determined as a percentage of the total number of cells. (c) Equal amounts of cell lysate were resolved on SDS-PAGE, transferred to nitrocellulose membranes, and probed with specific antibodies for cytochrome $c$, Bax, and PARP. $\beta$-Actin was used as an internal loading control. (d) THP-1 cells were collected following $24 \mathrm{~h}$ exposure to $4 \mathrm{mg} \mathrm{ml}^{-1}$ of ABE with or without $2 \mathrm{~h}$ of pretreatment with NAC. Caspase-3 activity was determined following the manufacturer's protocol. Each point represents the mean \pm SD of three independent experiments. The significance was determined by Student's $t$-test ( ${ }^{*} P<.05$ versus vehicle control). Cyto, Cytoplasm.

as compared with control, the percentage of cells in sub$\mathrm{G}_{0} / \mathrm{G}_{1}$ phase was increased than 10 -fold upon treatment with $4 \mathrm{mg} \mathrm{ml}^{-1} \mathrm{ABE}$ for $24 \mathrm{~h}$, but only increased more than 3-fold upon pretreatment with NAC. Figure 4(c) also shows that NAC decreased ABE-mediated Bax expression, cytochrome $c$ release and PARP cleavage in ABE-treated THP- 1 cells. In addition, the activation of caspase- 3 induced by $\mathrm{ABE}$ was markedly attenuated by pretreatment with NAC 


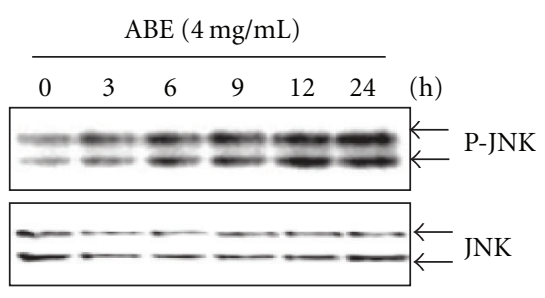

(a)

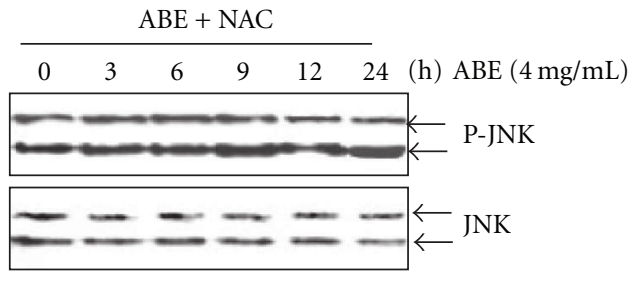

(b)

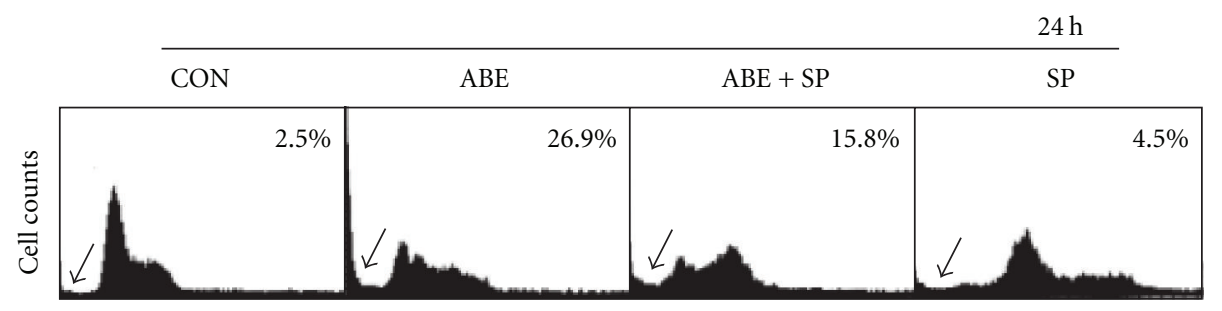

DNA contents

(c)

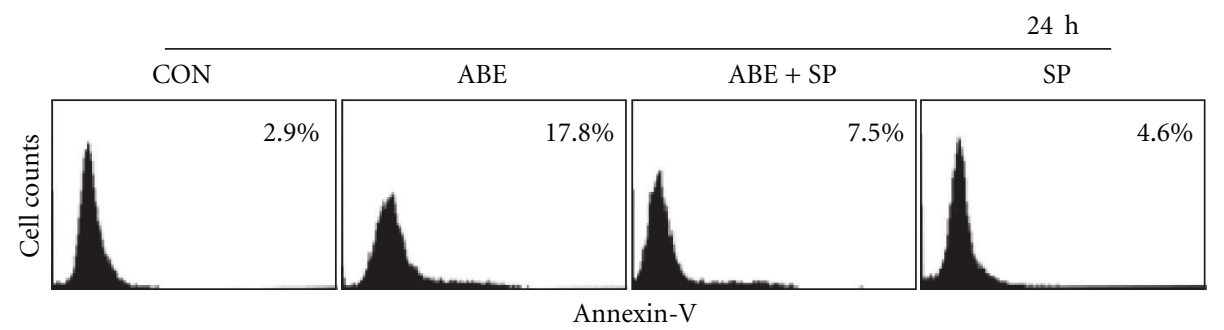

(d)

Figure 5: The role of JNK activation on ABE-mediated apoptosis. THP-1 cells $\left(2 \times 10^{5} \mathrm{cells} \mathrm{ml}^{-1}\right)$ were treated with $4 \mathrm{mg} \mathrm{ml} \mathrm{m}^{-1}$ of ABE for the indicated time. (a) Equal amounts of whole cell lysates were resolved by SDS-PAGE, transferred to nitrocellulose and probed with specific antibodies against p-JNK and JNK. (b) THP-1 cells were pretreated with $10 \mathrm{mM} \mathrm{NAC}$ and then $4 \mathrm{mg} \mathrm{ml}^{-1}$ of ABE was treated up to $24 \mathrm{~h}$. Then, the cells were lysated and western blot was performed using anti-p-JNK and anti-JNK antibodies. THP-1 cells were pretreated with SP600125 $(20 \mu \mathrm{M})$ for $2 \mathrm{~h}$ followed by ABE treatment $\left(4 \mathrm{mg} \mathrm{ml}^{-1}\right)$ for $24 \mathrm{~h}$. At the end of experiments, (c) DNA content and (d) annexin-V were analyzed by flow cytometer. SP, SP600125.

(Figure $4(\mathrm{~d}))$. These results suggest that the production of ROS plays an important role in ABE-mediated mitochondrial apoptotic pathways.

\subsection{JNK Activation Is a Potential Target in ABE-Induced} Apoptosis. As it has been shown that the ROS-mediated DNA damage triggers activation of JNK and subsequent cell death [4-6], we examined the status of JNK phosphorylation after ABE treatment. As shown in Figure 5(a), activation (phosphorylation) of JNK was significantly induced in a time-dependent manner and persisted for the duration of the experiment. On the other hand, the constitutive expression of JNK was not affected by ABE treatment. To further analyze whether ABE-induced ROS generation is responsible for JNK activation, cells were pretreated with NAC and then exposed to $\mathrm{ABE}$ up to $24 \mathrm{~h}$. As shown in Figure 5(b), pretreatment with NAC prevented the increased phosphorylation of JNK caused by ABE. To further analyze whether activation of JNK is responsible for $\mathrm{ABE}$-induced apoptosis, we exposed it to $20 \mu \mathrm{M}$ of SP600125, a JNK1/2 inhibitor for $2 \mathrm{~h}$, followed by treatment with $4 \mathrm{mg} \mathrm{ml}^{-1}$ of $\mathrm{ABE}$ for $24 \mathrm{~h}$. As shown in
Figures 5(c) and 5(d), pretreatment of SP600125 significantly suppressed $A B E$-induced sub- $G_{0} / G_{1}$ cell population and annexin- $\mathrm{V}^{+}$cells. These data confirm that treatment with $\mathrm{ABE}$ increases the production of ROS, leading to the activation of JNK.

3.5. ABE Inhibits Constitutive NF- $\kappa B$ Activation and NF$\kappa B$-Dependent IAPs. Because NF- $\kappa \mathrm{B}$ activation inhibits prolonged JNK activation and prevents the accumulation of ROS $[25,26]$, we examined the effect of $\mathrm{ABE}$ on the constitutive DNA-binding activity of NF- $\kappa \mathrm{B}$ and the NF- $\kappa \mathrm{B}-$ dependent responsive genes. First, THP-1 cells were treated with $4 \mathrm{mg} \mathrm{ml}^{-1} \mathrm{ABE}$ over increasing time periods, and we then performed EMSA. As shown in Figure 6(a), treatment with $\mathrm{ABE}$ inhibited constitutive NF- $\kappa \mathrm{B}$ binding activity in a time-dependent manner. The level of NF- $\kappa \mathrm{B}$ inhibition at $24 \mathrm{~h}$ exposure of $\mathrm{ABE}$ was found to be almost completely inhibited. A similar inhibitory effect of $\mathrm{ABE}$ on constitutive $\mathrm{NF}-\kappa \mathrm{B}$ binding activity at the $12 \mathrm{~h}$ time point was observed in a dose-dependent study (Figure 6(b)). Next, we confirmed the effect of $\mathrm{ABE}$ on constitutive NF- $\kappa \mathrm{B}$ activation in THP-1 


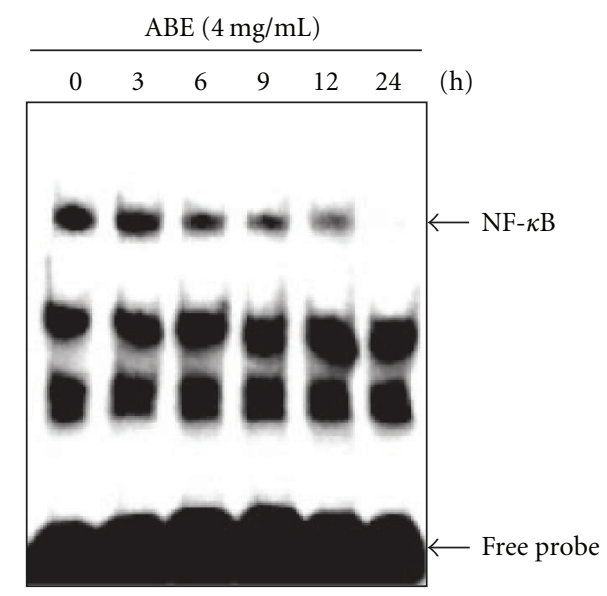

(a)

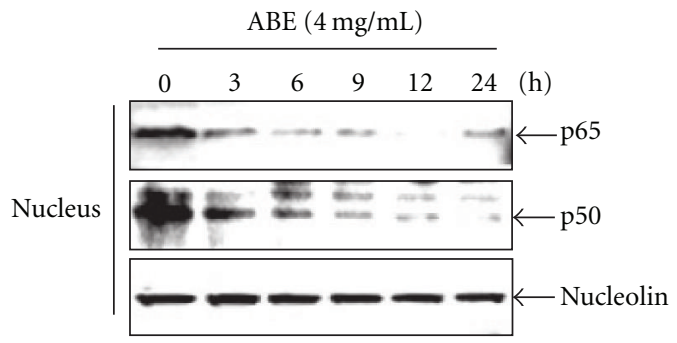

(c)

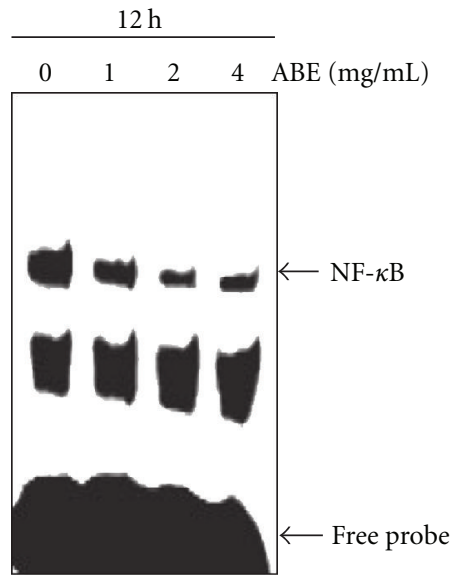

(b)

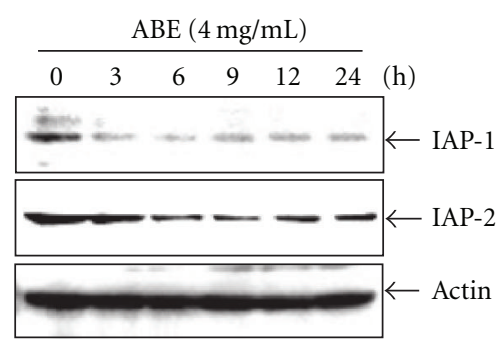

(d)

Figure 6: Effect of ABE on constitutive NF- $\kappa$ B activation in THP- 1 cells. THP-1 cells $\left(2 \times 10^{5}\right.$ cells ml $\left.{ }^{-1}\right)$ were incubated at $37^{\circ} \mathrm{C}$ with $(\mathrm{a})$ the indicated time duration of $4 \mathrm{mg} \mathrm{ml}^{-1}$ of $\mathrm{ABE}$ and (b) the indicated concentrations at $12 \mathrm{~h}$. DNA-binding activity of NF- $\kappa \mathrm{B}$ was analyzed by lightShiff ${ }^{\mathrm{TM}}$ chemiluminescent EMSA kit. (c) Western blots were performed for p65 and p50 protein levels in the nuclear extract. Nucleolin was used as an internal loading control. (d) Expression of IAP-1 and -2 was detected via western blot analysis. $\beta$-Actin was used as an internal loading control for cytoplasm. The results shown are from one representative experiment of three experiments that exhibited similar patterns.

cells by western blot analysis. As shown in Figure 6(c), ABE treatment resulted in a time-dependent decrease in protein levels of p65 and p50 in the nuclear extract.

Finally, we investigated whether ABE inhibits the NF$\kappa \mathrm{B}$-dependent transcriptional activated IAPs. Treatment with $4 \mathrm{mg} \mathrm{ml}^{-1}$ of ABE was examined for the expression of these genes via western blot analysis. As shown in Figure 6(d), treatment with ABE decreased the expressions of IAP-1 and -2 in a time-dependent manner, which is consistent with a decrease in NF- $\kappa \mathrm{B}$ activity. Therefore, it is possible that the induction of THP-1 cell apoptosis by ABE may be due to the inhibition of various anti-apoptotic factors.

\section{Discussion}

The present study reveals that $\mathrm{ABE}$ induced apoptosis through ROS-dependent JNK activation and inhibition of constitutively activated NF- $\kappa \mathrm{B}$ in human leukemic THP-1 cells. The ABE-induced ROS generation and activation of JNK that are associated with apoptotic cell death are significantly suppressed by pretreatment with NAC, indicating that ROS are the upstream-regulators of JNK activation during $\mathrm{ABE}$-induced apoptosis. Based on the results of the present study, the mechanism by which ABE induces apoptosis in THP- 1 cells is summarized in Figure 7.
Enhancement of ROS production has been associated with the apoptotic response induced by various chemotherapeutic agents [3-5]. ROS can cause apoptotic cell death via a variety of mechanisms, among which the activation of JNK plays a key role. It is identified by several reports indicating tumor necrosis factor-induced ROS production is responsible for sustained JNK activation in NF- $\kappa \mathrm{B}$-activation deficient cells [25-27]. Here, we show that ROS production in ABE-treated human leukemic THP-1 cells is markedly increased and functionally linked to JNK activation during apoptosis via the mitochondrial-dependent pathway. We further observed that an antioxidant NAC can regulate ROS detoxification, which inhibits JNK activation and decreases apoptosis induced by ABE. These results suggest that ROS accumulation contributes to ABE-induced cell death.

JNK, a stress-activated protein kinase, is activated by many stress stimuli such as UV and ionizing irradiation, heat shock, cycloheximide, anti-cancer agents and proinflammatory cytokines, all of which can induce apoptosis $[28,29]$. How activated JNK contributes to cell death is not clearly defined, but the production of tBid, a proteolytic fragment of Bid that specifically induces the release of mitochondrial Smac, points to JNK's role in JNK in promoting the initiation of the mitochondrial pathway of apoptosis [26]. Activated JNK has been also shown to phosphorylate 


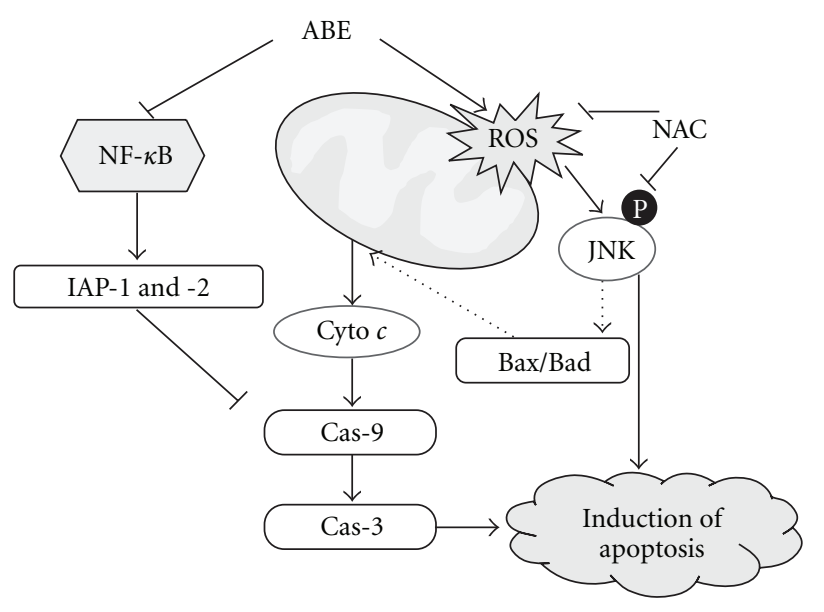

Figure 7: Proposed mechanisms for the apoptotic effects of ABE in THP-1 cells. The apoptotic mechanism was mediated by the generation of ROS, phosphorylation of JNK, release of cytochrome $c$ into cytoplasm, and activation of caspases. Additionally, expression of IAPs, which have inhibitory effect of caspases, was abolished by inhibition of NF- $\kappa$ B.

Bcl-2 and Bcl-xL, thereby inactivating their anti-apoptotic functions [26]. Whereas previous studies presented that NF$\kappa \mathrm{B}$ activation promotes cell survival by up-regulating the anti-apoptotic proteins' expression, including Bcl-2 as well as IAP families, and down-regulating the ROS-dependent JNK activation through suppression of the ROS accumulation $[27,30]$. NF- $\kappa \mathrm{B}$ activation can also maintain tumor cell viability, and inhibiting $\mathrm{NF}-\kappa \mathrm{B}$ activation alone can be sufficient to induce cell death $[31,32]$. In addition, the involvement of NF- $\kappa \mathrm{B}$ in chemoresistance may be related to its constitutive activation, such as human acute myelogenous leukemic cells [33]. Therefore, we used human leukemic THP-1 cells in this experiment as a model. Several reports have shown that NF- $\kappa \mathrm{B}$ inhibitors act as potent enhancers of chemotherapy-induced apoptosis [34]. In agreement with previous findings, ABE significantly inhibited constitutive $\mathrm{NF}-\kappa \mathrm{B}$ activation in vitro. NF- $\kappa \mathrm{B}$-dependent IAP- 1 and -2 were also suppressed in $\mathrm{ABE}$-treated cells. These data indicate that $\mathrm{ABE}$-induced NF- $\kappa \mathrm{B}$ inhibition enhances the apoptosis in ABE-treated cells, because decreased NF- $\kappa$ B activity could not prevent ABE-induced ROS-dependent sustained JNK activation.

In conclusion, our data indicate that human leukemic THP-1 cells are highly sensitive to growth inhibition and apoptosis induction by $\mathrm{ABE}$. ABE-induced apoptosis is associated with the mitochondrial pathway, and they are mediated by ROS generation and prolonged JNK activation. Taken together, ABE inhibits constitutive NF- $\kappa$ B activity and NF- $\kappa$ B-dependent IAP- 1 and -2 .

\section{Funding}

National R\&D Program for Cancer Control, Ministry of Health \& Welfare, Republic of Korea (no. 8020050).

\section{References}

[1] M. Inoue, E. F. Sato, M. Nishikawa et al., "Mitochondrial generation of reactive oxygen species and its role in aerobic life," Current Medicinal Chemistry, vol. 10, no. 23, pp. 24952505, 2003.

[2] I. Fridovich, "Fundamental aspects of reactive oxygen species, or what's the matter with oxygen?" Annals of the New York Academy of Sciences, vol. 893, pp. 13-18, 1999.

[3] W. Davis Jr., Z. Ronai, and K. D. Tew, "Cellular thiols and reactive oxygen species in drug-induced apoptosis," Journal of Pharmacology and Experimental Therapeutics, vol. 296, no. 1, pp. 1-6, 2001.

[4] P. Javvadi, A. T. Segan, S. W. Tuttle, and C. Koumenis, "The chemopreventive agent curcumin is a potent radiosensitizer of human cervical tumor cells via increased reactive oxygen species production and overactivation of the mitogenactivated protein kinase pathway," Molecular Pharmacology, vol. 73, no. 5, pp. 1491-1501, 2008.

[5] S. V. Singh, S. K. Srivastava, S. Choi et al., "Sulforaphaneinduced cell death in human prostate cancer cells is initiated by reactive oxygen species," Journal of Biological Chemistry, vol. 280, no. 20, pp. 19911-19924, 2005.

[6] C. C. C. Wang, Y.-M. Chiang, S.-C. Sung, Y.-L. Hsu, J.-K. Chang, and P.-L. Kuo, "Plumbagin induces cell cycle arrest and apoptosis through reactive oxygen species/c-Jun N-terminal kinase pathways in human melanoma A375.S2 cells," Cancer Letters, vol. 259, no. 1, pp. 82-98, 2008.

[7] F. R. Greten and M. Karin, "The IKK/NF- $\kappa$ B activation pathway-a target for prevention and treatment of cancer," Cancer Letters, vol. 206, no. 2, pp. 193-199, 2004.

[8] J. Suh and A. B. Rabson, "NF- $\kappa$ B activation in human prostate cancer: important mediator or epiphenomenon?" Journal of Cellular Biochemistry, vol. 91, no. 1, pp. 100-117, 2004.

[9] Y. Ben-Neriah, "Regulatory functions of ubiquitination in the immune system," Nature Immunology, vol. 3, no. 1, pp. 20-26, 2002.

[10] M. Karin and A. Lin, "NF- $\kappa$ B at the crossroads of life and death," Nature Immunology, vol. 3, no. 3, pp. 221-227, 2002.

[11] S. A. Keller, E. J. Schattner, and E. Cesarman, "Inhibition of $\mathrm{NF}-\kappa \mathrm{B}$ induces apoptosis of KSHV-infected primary effusion lymphoma cells," Blood, vol. 96, no. 7, pp. 2537-2542, 2000.

[12] W.-S. Jeong, I.-W. Kim, R. Hu, and A.-N. T. Kong, "Modulatory properties of various natural chemopreventive agents on the activation of NF- $\kappa$ B signaling pathway," Pharmaceutical Research, vol. 21, no. 4, pp. 661-670, 2004.

[13] Y. Takada, S. Singh, and B. B. Aggarwal, "Identification of a p65 peptide that selectively inhibits NF- $\kappa$ B activation induced by various inflammatory stimuli and its role in down-regulation of NF- $\kappa \mathrm{B}$-mediated gene expression and upregulation of apoptosis," Journal of Biological Chemistry, vol. 279, no. 15, pp. 15096-15104, 2004.

[14] E. Zandi, D. M. Rothwarf, M. Delhase, M. Hayakawa, and M. Karin, "The I $\kappa \mathrm{B}$ kinase complex (IKK) contains two kinase subunits, IKK $\alpha$ and IKK $\beta$, necessary for I $\kappa \mathrm{b}$ phosphorylation and NF- $\kappa$ B activation," Cell, vol. 91, no. 2, pp. 243-252, 1997.

[15] I. Lavi, D. Friesem, S. Geresh, Y. Hadar, and B. Schwartz, "An aqueous polysaccharide extract from the edible mushroom Pleurotus ostreatus induces anti-proliferative and proapoptotic effects on HT-29 colon cancer cells," Cancer Letters, vol. 244, no. 1, pp. 61-70, 2006.

[16] U. Lindequist, T. H. J. Niedermeyer, and W.-D. Jülich, "The pharmacological potential of mushrooms," Evidence-Based 
Complementary and Alternative Medicine, vol. 2, no. 3, pp. 285-299, 2005.

[17] H. Kawagishi, A. Nomura, T. Yumen, T. Mizuno, T. Hagiwara, and T. Nakamura, "Isolation and properties of a lectin from the fruiting bodies of Agaricus blazei," Carbohydrate Research, vol. 183, no. 1, pp. 150-154, 1988.

[18] N. Ohno, M. Furukawa, N. N. Miura, Y. Adachi, M. Motoi, and T. Yadomae, "Antitumor $\beta$-glucan from the cultured fruit body of Agaricus blazei," Biological and Pharmaceutical Bulletin, vol. 24, no. 7, pp. 820-828, 2001.

[19] M. Kawamura and H. Kasai, "Delayed cell cycle progression and apoptosis induced by hemicellulase-treated Agaricus blazei," Evidence-Based Complementary and Alternative Medicine, vol. 4, no. 1, pp. 83-94, 2007.

[20] W.-S. Ahn, D.-J. Kim, G.-T. Chae et al., "Natural killer cell activity and quality of life were improved by consumption of a mushroom extract, Agaricus blazei Murill Kyowa, in gynecological cancer patients undergoing chemotherapy," International Journal of Gynecological Cancer, vol. 14, no. 4, pp. 589-594, 2004.

[21] K.-I. Oshiman, Y. Fujimiya, T. Ebina, I. Suzuki, and M. Noji, "Orally administered $\beta$-1,6-D-polyglucose extracted from Agaricus blazei results in tumor regression in tumor-bearing mice," Planta Medica, vol. 68, no. 7, pp. 610-614, 2002.

[22] G.-Y. Kim, M.-Y. Lee, H.-J. Lee et al., "Effect of water-soluble proteoglycan isolated from Agaricus blazei on the maturation of murine bone marrow-derived dendritic cells," International Immunopharmacology, vol. 5, no. 10, pp. 1523-1532, 2005.

[23] C. Y. Jin, Y. H. Choi, D. O. Moon et al., "Induction of $\mathrm{G}_{2} / \mathrm{M}$ arrest and apoptosis in human gastric epithelial AGS cells by aqueous extract of Agaricus blazei," Oncology Reports, vol. 16, no. 6, pp. 1349-1355, 2006.

[24] C.-Y. Jin, D.-O. Moon, Y. H. Choi, J.-D. Lee, and G.-Y. Kim, "Bcl-2 and caspase-3 are major regulators in Agaricus blazei-induced human leukemic U937 cell apoptosis through dephoshorylation of Akt," Biological and Pharmaceutical Bulletin, vol. 30, no. 8, pp. 1432-1437, 2007.

[25] C. Bubici, S. Papa, K. Dean, and G. Franzoso, "Mutual crosstalk between reactive oxygen species and nuclear factor-kappa B: molecular basis and biological significance," Oncogene, vol. 25, no. 51, pp. 6731-6748, 2006.

[26] A. Wullaert, K. Heyninck, and R. Beyaert, "Mechanisms of crosstalk between TNF-induced NF- $\kappa \mathrm{B}$ and JNK activation in hepatocytes," Biochemical Pharmacology, vol. 72, no. 9, pp. 1090-1101, 2006.

[27] S. Sakon, X. Xue, M. Takekawa et al., "NF- $\kappa$ B inhibits TNFinduced accumulation of ROS that mediate prolonged MAPK activation and necrotic cell death," The EMBO Journal, vol. 22, no. 15, pp. 3898-3909, 2003.

[28] A. Iwamaru, E. Iwado, S. Kondo, R. A. Newman, B. Vera, A. D. Rodríguez et al., "Eupalmerin acetate, a novel anticancer agent from Caribbean gorgonian octocorals, induces apoptosis in malignant glioma cells via the c-Jun NH2-terminal kinase pathway," Molecular Cancer Therapeutics, vol. 6, pp. 184-192, 2007.

[29] J. M. Kyriakis, P. Banerjee, E. Nikolakaki et al., "The stressactivated protein kinase subfamily of c-jun kinases," Nature, vol. 369, no. 6476, pp. 156-160, 1994.

[30] C. G. Pham, C. Bubici, F. Zazzeroni et al., "Ferritin heavy chain upregulation by NF- $\kappa \mathrm{B}$ inhibits TNF $\alpha$-induced apoptosis by suppressing reactive oxygen species," Cell, vol. 119, no. 4, pp. 529-542, 2004.

[31] E. D. Cahir-McFarland, D. M. Davidson, S. L. Schauer, J. Duong, and E. Kieff, "NF- $\kappa$ B inhibition causes spontaneous apoptosis in Epstein-Barr virus-transformed lymphoblastoid cells," Proceedings of the National Academy of Sciences of the United States of America, vol. 97, no. 11, pp. 6055-6060, 2000.

[32] M. L. Guzman, S. J. Neering, D. Upchurch et al., "Nuclear factor- $\kappa \mathrm{B}$ is constitutively activated in primitive human acute myelogenous leukemia cells," Blood, vol. 98, no. 8, pp. 23012307, 2001.

[33] C. Nakanishi and M. Toi, "Nuclear factor- $\kappa \mathrm{B}$ inhibitors as sensitizers to anticancer drugs," Nature Reviews Cancer, vol. 5, no. 4, pp. 297-309, 2005.

[34] K. M. W. Rahman, S. Ali, A. Aboukameel et al., "Inactivation of NF- $\kappa$ B by 3,3'-diindolylmethane contributes to increased apoptosis induced by chemotherapeutic agent in breast cancer cells," Molecular Cancer Therapeutics, vol. 6, no. 10, pp. 27572765, 2007. 


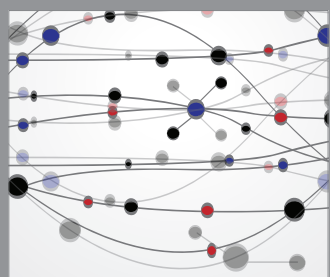

The Scientific World Journal
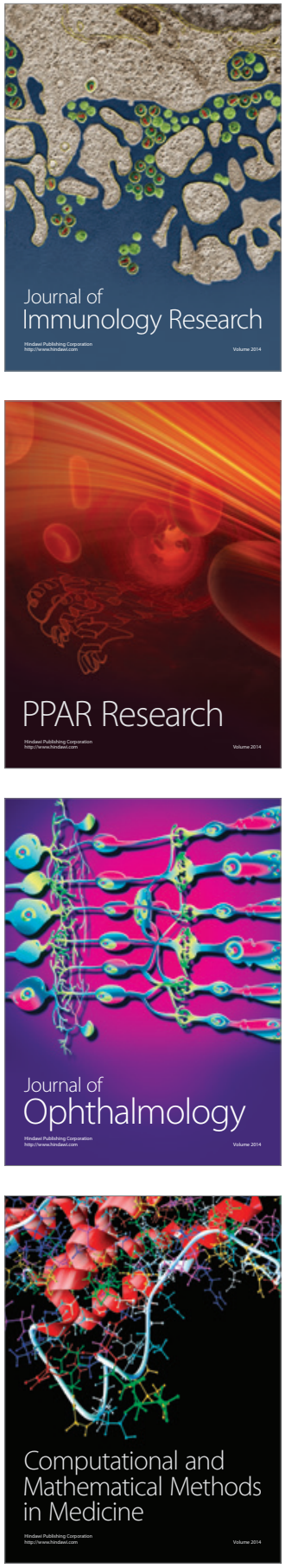

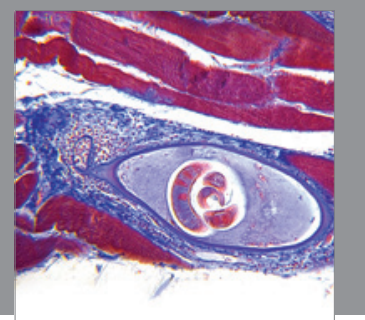

Gastroenterology

Research and Practice
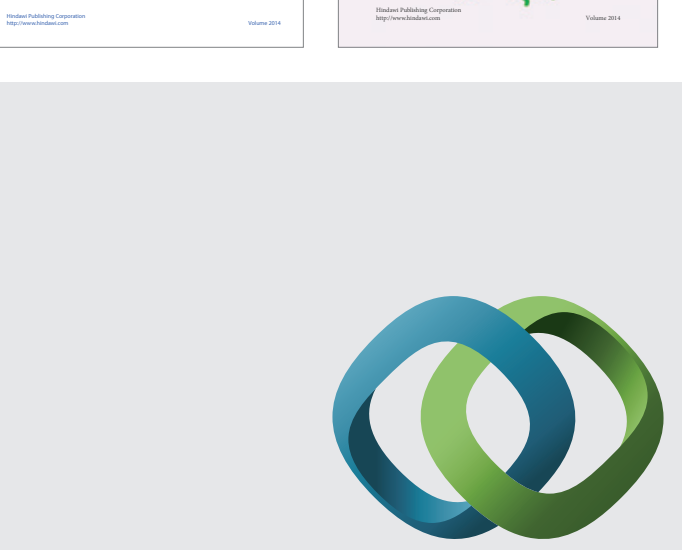

\section{Hindawi}

Submit your manuscripts at

http://www.hindawi.com
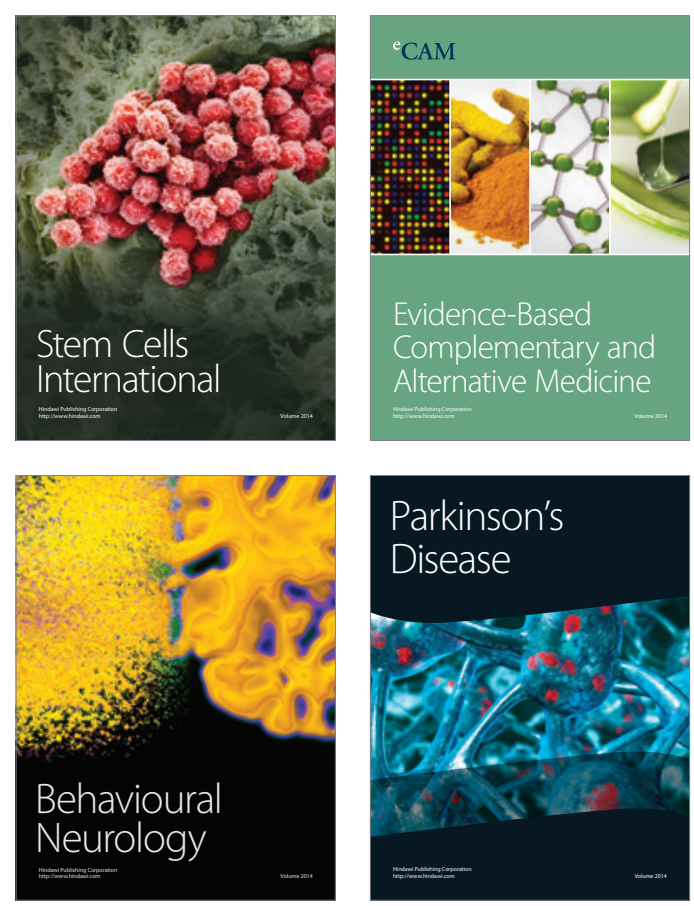

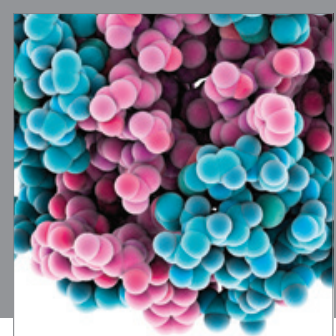

Journal of
Diabetes Research

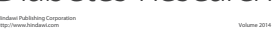

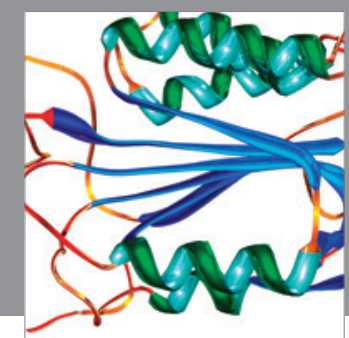

Disease Markers
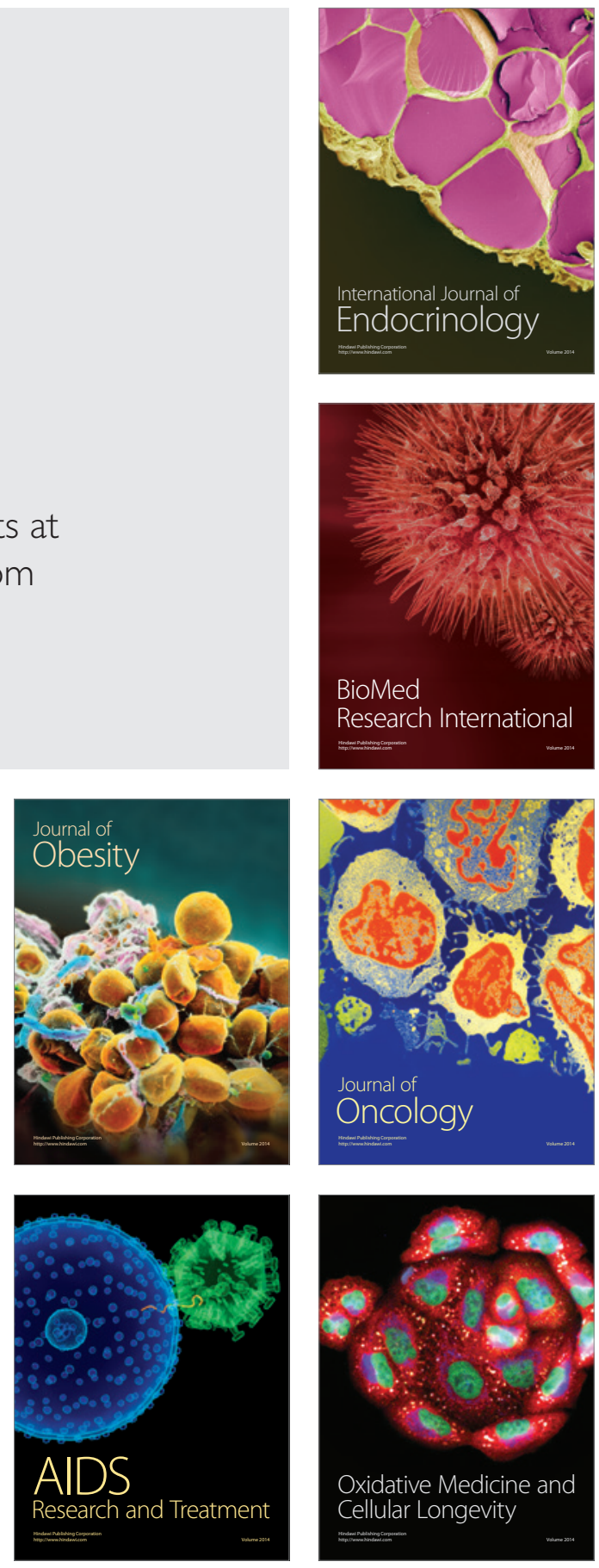